\title{
Synchronous versus Asynchronous E-Learning Practical Training on Acquiring Knowladge and Skills for Pediatric Physical Therapy Students
}

\author{
NADA ELGHARIEB, M.Sc. and FATEN HASSAN ABDELAZEIM, Ph.D. \\ The Department of Growth and Developmental Disorders in Children and its Surgery, Faculty of Physical Therapy, \\ Cairo University
}

\begin{abstract}
Background: E-learning is the use of electronic devices to conduct teaching synchronously or asynchronously, that allow students to learn from different places especially during pandemic COVID 19.

Aim of Study: This study aims to find out which form of e-learning synchronous or asynchronous practical training more effective to acquire knowledge and skills for pediatric physical therapy students.

Patients and Methods: Seventy-five undergraduate (5 th grade and internship) students selected randomly from different universities, students randomly allocated in two groups, thirty seven students in group A receive synchronous e-learning through zoom life session, thirty eight students in group B receive asynchronous e-learning through recorded video, students knowledge and skills assessed by online quiz designed on Google forms platform, the study carried out from December 2020 to April 2020.

Result: There was a significant increase in the quiz total score of group B compared with that of group A $(p=0.003)$ $(p<0.05)$

Conclusion: The result suggested that asynchronous elearning is more effective than synchronous e-learning to acquire knowledge and skills for pediatric physical therapy students.
\end{abstract}

Key Words: E-learning - Synchronous learning - Asynchronous learning - Practical training.

\section{Introduction}

COVID 19 is pandemic caused by SAR $\mathrm{CO} 2$ virus until now it negatively affect many fields allover the world one of them is educational field as countries continue lockdown to avoid virus spread as the main factor which help rapid spread of COVID 19 is direct contact between people such as in

Correspondence to: Dr. Nada Elgharieb, E-Mail: nadamohy94@gmail.com schools, universities and celebrities, but the educate process must be continued with specific way to avoid or minimize physical contact, many schools and universities directed to shift toward use of distance learning to cope with the current issue.

E-learning is the use of electronic devices and technology to conduct teaching such as the intranet, World Wide Web, and multi-media based Computer or mobile applications Another synonymous of elearning are computer assisted, web based learning and online learning [1].

Synchronous e-learning called real time or community oriented online learning, which provide active learning environment as it connect students and allow them to participate from different places at the same time, this type of e-learning conducted through videoconferencing and online chats, nowadays this type is spread rapidly as it overcome social isolation problem as it allow the learners to interact with each other and with the teacher [2].

Asynchronous e-learning It's a self-paced learning or student centered learning, conducted via email, discussion board, recorded audio or videos, it offer time flexibility as students able to learn when time available according to his tailored schedule [3].

Medical schools also started to use e-learning in different disciplines, Systematic review done by Pei and $\mathrm{Wu}$, [4] to compare between effects of online and offline learning on under graduate medical students, the online group use massive open online courses (MOOCs), online learning, $\mathrm{M}$ learning and videos the reviewers collect 16 article from 2000 to 2017, after analysis of data the study 
found that 7 articles reported that no significant difference between both groups and 9 articles reported significant difference improvement toward online learning group.

\section{Patients and Methods}

\section{Subjects:}

Seventy five undergraduate physical therapy students in 5 th grade and internship selected randomly from seven universities (Cairo, 6 Oct, misr, MTI, pharos, deraya and delta UNIV), they were randomly allocated between two groups (A,B), 37 students in group A received practical training about application of $\mathrm{k}$ taping in children through synchronous e-learning and 38 students received the same practical training but through asynchronous e-learning method, all students entered the study having their informed consent.

\section{Inclusion criteria:}

1- Physical therapy student in pediatric round (5 th grade and internship).

2- Have facility to access internet (mobile, laptop, tablets and connection with internet).

\section{Exclusion criteria:}

Student excluded from the study if they have previous knowledge about the topic of the clinical practical session.

\section{Materials:}

Laptop or mobile phone with internet access, Camera, Power point presentation about $\mathrm{k}$ taping application for children, Case model for practical training and online quiz for assessment.

\section{Procedures:}

\section{For intervention:}

Group (A) synchronous e-learning: Students received practical training about $\mathrm{k}$ taping application for children to correct problems related to hand and forearm through zoom meeting application, its one life session last for 60min, first start with demonstration about $\mathrm{k}$ taping application then shared videos on zoom to further explain step by step k taping application for each separate problem, each student had opportunity to share their screen to practice application and ask for any explanation.

Group (B) asynchronous e-learning received the same practical training but through recorded video contain the same content of PowerPoint presentation and videos for hands on application, students asked to communicate on what's app group if they needed further explanation of specific points.

\section{For assessment:}

Online quiz had been designed on Google forms platform according to intended learning outcomes, questions assess knowledge and skills, contain 5 multiple choice questions each question score was 2 points, quiz sent to each student in group B separately on e mail or what's app immediately after they finished the recorded videos according to their time availability but group A answered quiz which had been sent on what's app chat group at one time.

\section{Statistical analysis:}

Statistical analysis was conducted through the statistical package for social studies (SPSS) version 22 for windows (IBM SPSS, Chicago, IL, USA), Chi squared test was conducted for comparison of university, academic year and sex distribution between groups. Unpaired $t$-test was conducted for comparison of quiz total score between groups, the level of significance for all statistical tests was set at $p<0.05$.

\section{Results}

\section{Subject characteristics:}

Table (1) showed the subject characteristics of the group A and B. There was no significant difference of university, academic year (Fig. 1) and sex distribution (Fig. 2$)$ between groups $(p>0.05)$.

Table (1): Comparison of subject characteristics between group A and B.

\begin{tabular}{|c|c|c|c|c|}
\hline & Group A & Group B & $\begin{array}{c}\text { X2- } \\
\text { value }\end{array}$ & $\begin{array}{c}p- \\
\text { value }\end{array}$ \\
\hline \multicolumn{5}{|l|}{ University } \\
\hline \multicolumn{5}{|l|}{ distribution: } \\
\hline Cairo & $25(67.6 \%)$ & $27(71.1 \%)$ & 5.29 & 0.54 \\
\hline 6-Oct & $3(8.1 \%)$ & $6(15.8 \%)$ & & \\
\hline Delta & $5(13.5 \%)$ & $2(5.3 \%)$ & & \\
\hline Misr & $2(5.4 \%)$ & $0(0 \%)$ & & \\
\hline Deraya & $0(0 \%)$ & $1(2.6 \%)$ & & \\
\hline Pharos & $1(2.7 \%)$ & $1(2.6 \%)$ & & \\
\hline MTI & & $1(2.6 \%)$ & & \\
\hline \multicolumn{5}{|c|}{ Academic year: } \\
\hline 5th year & $15(40.5 \%)$ & $16(42 \%)$ & 0.01 & 0.89 \\
\hline Intern & $22(59.5 \%)$ & $22(58 \%)$ & & \\
\hline \multicolumn{5}{|l|}{ Sex: } \\
\hline Females & $27(73 \%)$ & $30(79 \%)$ & 0.36 & 0.54 \\
\hline Males & $10(27 \%)$ & $8(21 \%)$ & & \\
\hline
\end{tabular}



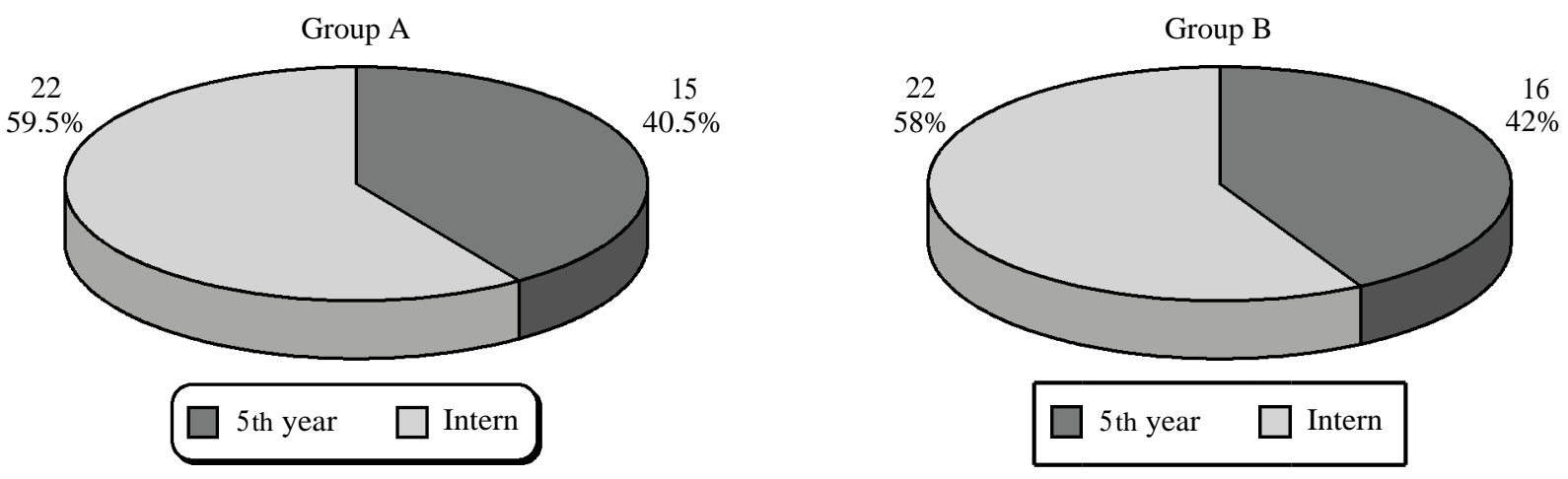

Fig. (1): Academic year distribution of the group A and B.
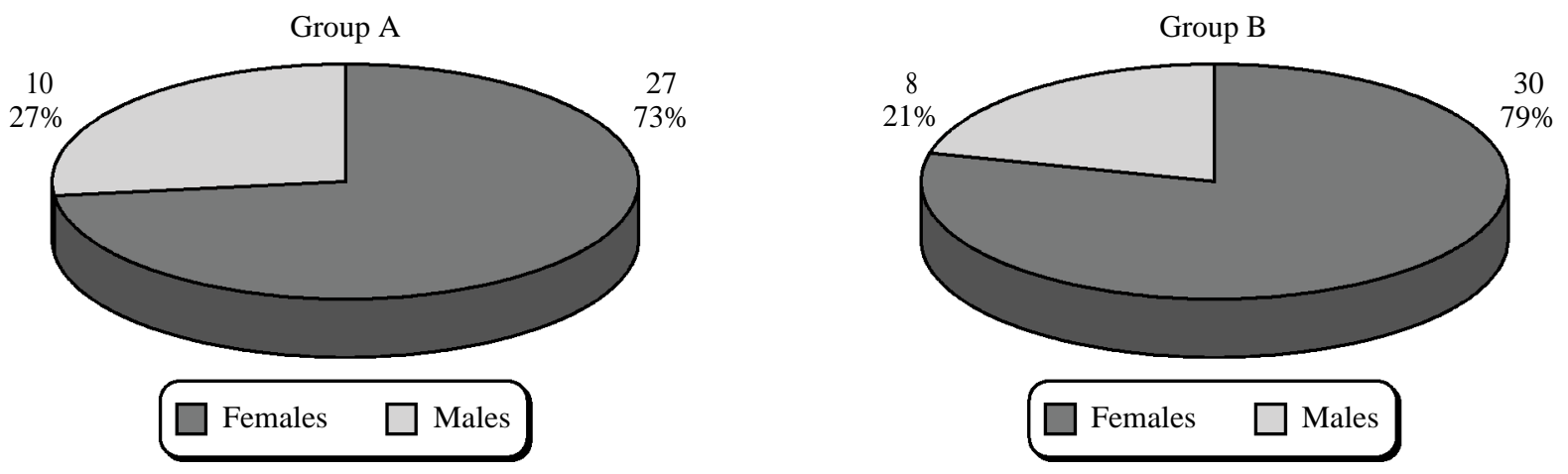

Fig. (2): Sex distribution of the group A and B.

Comparison of quiz total score between group $A$ and $B$ :

As shown in Table (2), Fig. (3) the mean quiz total score of group A was $6.91 \pm 2.47$ and that of group B was $8.52 \pm 1.95$. The mean difference between both groups was -1.61 . There was a significant increase in the quiz total score of group B compared with that of group A $(p=0.003)$.

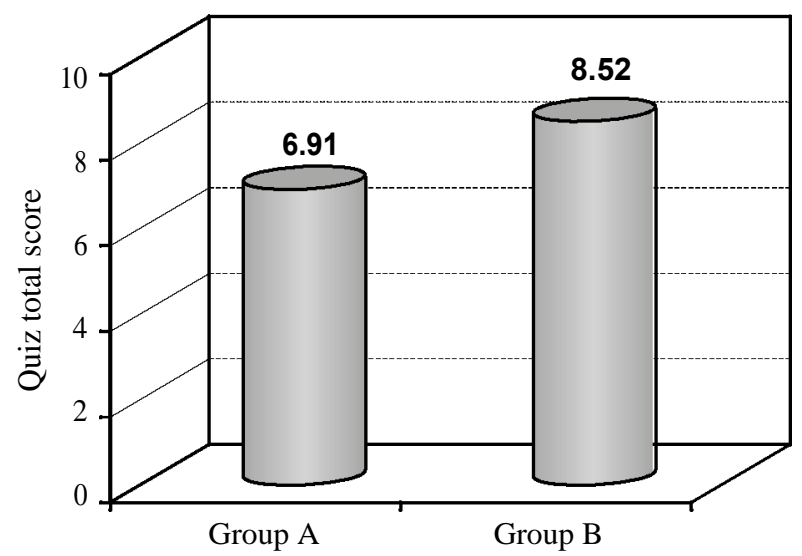

Fig. (3): Mean quiz total score of group A and B.
Table (2): Comparison of quiz total score between group A \&B.

\begin{tabular}{lcccccc}
\hline & $\begin{array}{c}\text { Group A } \\
\text { X } \pm \text { SD }\end{array}$ & $\begin{array}{c}\text { Group B } \\
\text { X } \pm \text { SD }\end{array}$ & MD & $\begin{array}{c}t- \\
\text { value }\end{array}$ & $\begin{array}{c}p- \\
\text { value }\end{array}$ & Sig. \\
\hline Quiz & $6.91 \pm 2.47$ & $8.52 \pm 1.95$ & -1.61 & -3.12 & 0.003 & $\mathrm{~S}$ \\
total & & & & & & \\
score & & & & & & \\
\hline
\end{tabular}

\begin{tabular}{ll}
\hline MD: Mean difference. & SD: Standard deviation. \\
Mean X. & $t$-value: Unpaired $t$-value \\
$p$-value: Probability value. & S: Significant.
\end{tabular}

\section{Discussion}

The current study done to help pediatric physical therapy students to find out which form of elearning (synchronous or asynchronous) more effective to continue practical training to acquire knowledge and skills in concurrent with lockdown during COVID 19.

The present result of online quiz score which measure students improvement in knowledge and skills after practical training through both synchronous and asynchronous e-learning reported that asynchronous e-learning through recorded video enhance knowledge and skills more than synchro- 
nous e-learning delivered through zoom life session as the mean total score of group $\mathrm{A}=6.91$ ( $\mathrm{SD} \pm$ 2.47 ) while group $\mathrm{B}=8.52$ ( $\mathrm{SD} \pm 1.95)$.

The results of the current study match with a study conducted by Al Soufi et al., [5], on Libyan medical students found that about $56 \%$ of students prefer video lecture than live lecture.

Another study conducted by Chang et al., [6] comes in to support our result, reported that asynchronous e-learning enhance medical knowledge between students as the study use it as delivery method to teach curriculum in the pediatric emergency medicine rotation.

Study conducted by Sinclair et al., [7] to measure the effect of asynchronous e-learning on general practice nurse knowledge about chronic kidney disease risk factor, reported that a significant improvement between pre and post test score.

From the current result it is suggested that asynchronous e-learning better than synchronous e-learning to deliver practical training and improve skills for pediatric physical therapy students, as the asynchronous e-learning give students flexibility to learn at any time and avoid struggling to attend the lecture [8].

According to Marom et al., [9] study that come in to support this suggestion, the study found that two third of participating students prefer asynchronous learning over synchronous learning environment as it remove time barrier and provide flexibility.

Pappas, [10] said that some students have poor communication skills which prevent them from working in team and exchange knowledge so asynchronous e-learning offer them opportunity to focus and process information without stress.

\section{Conclusion:}

Based on the study result, it could be concluded that asynchronous e-learning better than synchronous e-learning to acquire knowledge and skills for pediatric physical therapy students.

\section{References}

1- KIM S.: The Future of e-Learning in medical education: Current trend and future opportunity. J. Educ. Eval Health Prof., 3: 3, 2006.

2- TAMM S.: Types of e-learning. E-Student, 2019.

3- HRASTINKSI S.: Asynchronous and synchronous elearning. Educause Quarterly, 4, 2008.

4- PEI L. and WU H.: Does online learning work better than offline learning in undergraduate medical education? A systematic review and meta-analysis. Medical Education Online, 24, 2019.

5- ALSOUFI A., ALSUYIHILI A., MSHERGHI A., et al.: Impact of the COVID-19 pandemic on medical education: Medical students' knowledge, attitudes, and practices regarding electronic Learning. Plos One., 15 (11), 2020.

6- CHANG T.P., PHAM P.K., SOBOLEWSKI B., et al.: Pediatric emergency medicine e-learning: A multicenter randomized controlled Solomon four-group study. Acad. Emerg Med., 21 (8): 912-9, 2014.

7- SINCLAIR P.M., KABLE A., LEVETT-JONES T., HOLDER C. and OLDMEADOW C.J.: An evaluation of general practice nurses knowledge of chronic kidney disease risk factors and screening practices following completion of a case study-based asynchronous e-learning module. Aust. J. Prim Health, 25 (4): 346-352, 2019.

8- MAKHLOUF J.: The benefits and disadvantages of asynchronous learning. ELM learning, 2014.

9- BEYTH-MAROM R., CASPI A. and SAPORTA K.: Synchronous vs. asynchronous tutorials. Journal of Research on Technology Education, 37 (3), 2005.

10- PAPPAS C.: Producing high quality elearning videos: The ultimate guide. ELearning Design and Development, 2015. 


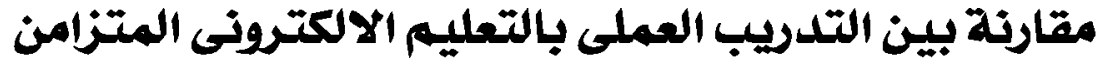

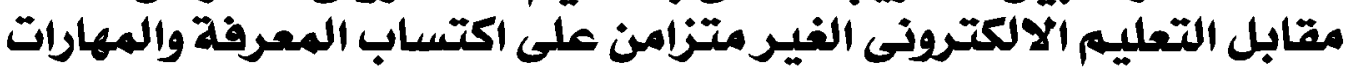 لطلاب العلاج الطبيعى بقيسم الإطفال}

والمهارات لطلاب العلاج الطبيعى بقدس لمعرفة تأثير التكريب العملى بالتعليم الالكترونى المتزامن مقابل التعليم الالكترونى الغير متزامن على اكتساب المعرفة

شارك فى الدراسة طالب وطالبة وتم اختيارهم عشوائياً من جامعات مختلة ثم تم تفيعهم عشوائياً بين مجموعتين.

المجموعة الأولى احتوت على Vr طالب وطالبة وتلقوا تدريب عملى عن كيفية تطبيق الشريط اللاصق المن على حالات مختلة من الاطفال

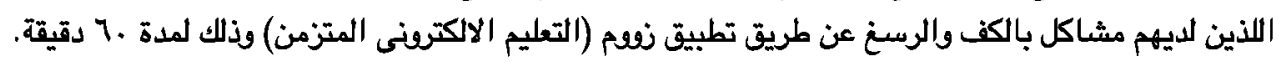

المجموعة الثانية احتوت على ^ץ طلب وطالبة وتلقوا نفس التكريب العملى للمجموعة الأولى ولكن عن طريق فيديو مسجل سابقاً (التعليم

الالكترونى الفير متزامن).

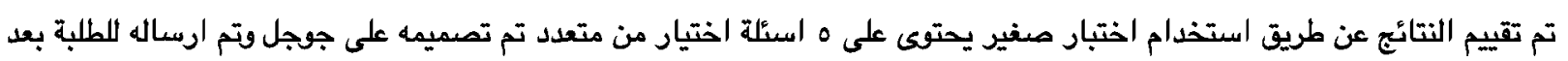

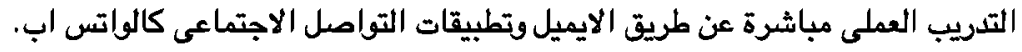

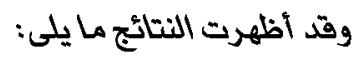

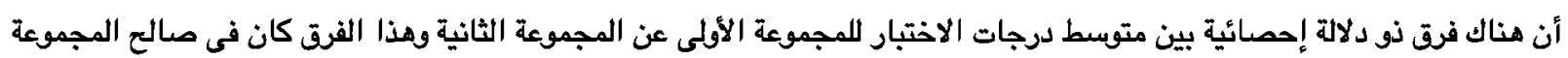

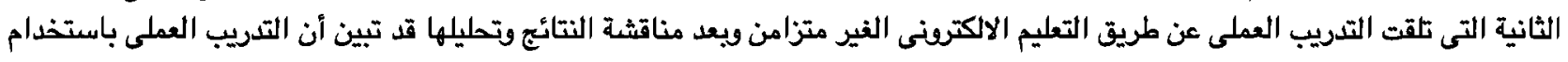

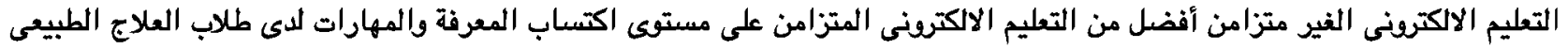

